\title{
CORRESPONDENCE
}

\section{Opposition in Morocco}

Sir,

In May 1963, Morocco's UNFP explained that its participation in the legislative elections was not to be interpreted as a form of reconciliation with King Hassan's regime of 'personal power'. The party executive stated that: 'It is not a question of ameliorating the regime, of altering it or of standing bail for it. For the UN F P it is a question of its abolition.' Perhaps it was aggressive statements of this kind that led Jacques Robert, in his article "Typology of Opposition: Opposition and Control in Tunisia, Morocco, and Algeria', to assert that the UNFP 'will remain in opposition until its claims (often revolutionary) are met.' (p. 395)

However M. Robert never defines just what claims the UNFP has made nor which among them are 'revolutionary'. This shortcoming in his article can probably be attributed to limitations of space, but, for all that, a few supplementary remarks are warranted.

Ringing declarations of the UNFP, such as that cited above, may have been designed to mask a less-than-total opposition to the Moroccan regime - they may also have helped ward off UMT accusations of compromise with 'feudalism'. But it would be wrong to construe UNFP public utterances as hard evidence for an uncompromising attitude toward the present regime, and this, I fear, is the impression that $M$. Robert gives. On p. $3^{89}$ the author claims that the emergency powers assumed by King Hassan in June of 1965 came as a result of "... the stubborn refusal of a constitutional opposition to accept repeated offers of national unity ...' While there is not space here to examine, just why the king did proclaim the state of exception, I would point out that in his spring negotiations with Prince Moulay Ali, Morocco's ambassador to France, Mehdi Ben Barka was willing to consider UNFP participation in a government in which it would control only three ministries (agriculture, economy, education). One should also take note of the presence of UNFP members in the government: Abdulhamid Zemmouri, Minister of Commerce; Naceur ben Larbi, Director of the BRPM; and Ahmad Lasky, Minister of Public Works. Though anomalous, their presence is nonetheless real.

A few comments on M. Robert's typology of North African opposition may help to clarify the specific position of the UNFP. While M. Robert correctly identifies the dual sources of opposition in the Maghreb, his treatment of their organizational manifestations is inadequate. Let us distinguish between organizations, parties or otherwise, whose objective is the total reorganization of a given regime and those whose objective is to extract favours and gain positions from a regime as a result of tactical opposition. Grosso modo one may say that the traditionalist Islamic opposition in the Maghreb, when it has organizational form, adopts a position of tactical opposition. Its opposition is defensive, aimed at the protection of acquired rights, values and institutions. Nowhere in the 


\section{GOVERNMENT AND OPPOSITION}

Maghreb does there exist a movement of the nature of Egypt's Ikhwan al-Muslimin that seeks the complete re-ordering of society according to Islamic principles. For instance in Morocco the Istiqlal party has, since I963, adopted a stance of tactical opposition. Its repeated denunciations of 'personal power' and other aspects of the present regime serve the purpose of establishing the party's bargaining position vis $\dot{a}$ vis the palace. Conversely, after its formation in 1959, the UNFP presented the image of the system-challenging opposition, uninterested in short-term advantages. Grouping elements of the resistance, all the UMT, and several gifted members of the Istiqlal, the UNFP became a victim of its own initial élan. Its leaders over-estimated their following and under-estimated the resiliency of the palace and the Istiglal. They adopted an aggressive attitude because such an attitude appeared at the time feasible. But by I96I the resistance elements had been regrouped or dispersed by the palace, and the UMT drifted into 'economic unionism', for the very cogent reasons set forth by $M$. Robert on p. 397. The plot trial of $1963-64$ provided the coup de grâce, decimating the UNFP's never very formidable organization. That left the UNFP with a handful of politicos and a following of petty bureaucrats, Soussi merchants, and students. The élan is dead as is the feasibility of intransigence. The UNFP, with what force it can yet muster, has slipped, willy-nilly, into tactical opposition. It must now bargain for its continued existence and put away its dreams of social revolution for better days.

Finally I feel compelled to take exception to the author's statement (p. 403) that: 'Between a rigid Marxism ... and a reactionary and aggressive Islamism . . . , there is a no-man's land which no one actually occupies.' To the contrary, between poles so widely separated one can find a wellinhabited intermediate zone, peopled, among others, by Morocco's opposition and in Tunisia by the Socialist Destour. Rigidity, Marxist or otherwise, is a luxury that the North African politician can ill afford. 'Reactionary and aggressive Islamism', if it ever existed in the Maghreb, probably died with Ben Badis, is certainly not incarnate in Allal al-Fassi, and was, in large part, a straw-man of some French imagination.

Yours faithfully

John Waterbury

Dept. Public Law and Government

Columbia University

At present in Rabat under the auspices of Foreign Area Fellowship Programme 